\title{
Synchronization of Cell Division in the Fission Yeast Schizosaccharomyces pombe by Ethylenediaminetetra-acetic Acid
}

\author{
By BHAVNA AHLUWALIA, * JOHN H. DUFFUS, \\ LINDA J. PATERSON AND GRAEME M. WALKER \\ Department of Brewing and Biological Sciences, Heriot-Watt University, \\ Edinburgh EH1 $1 H X$, Scotland
}

(Received 13 February 1978)

\begin{abstract}
When cultures of Schizosaccharomyces pombe growing exponentially in a minimal medium were treated, with $50 \mathrm{~mm}$-EDTA for $1 \mathrm{~h}$, nucleic acid synthesis was inhibited but protein synthesis was not. On transfer to fresh medium, $50 \%$ of the cells divided synchronously. These phenomena may be explained on the basis of reduced availability of $\mathbf{M g}^{2+}$ following chelation with EDTA.
\end{abstract}

\section{INTRODUCTION}

Cell division in yeast may be synchronized by altering intracellular $\mathrm{Mg}^{2+}$ and $\mathrm{Ca}^{2+}$ concentrations using the ionophore A23187 (Duffus \& Paterson, 1974a; Penman \& Duffus, 1975). We have postulated that a continuous fall in intracellular $\mathrm{Mg}^{2+}$ concentration through the cell cycle may play a crucial part in the volume-related regulation of cell division (Duffus \& Paterson," $1974 b$ ). If this is so, any factor which alters the intracellular $\mathrm{Mg}^{2+}$ concentration to a constant level may be expected to cause division synchrony. Thus we decided to test the effect of the divalent cation chelating agent EDTA, which might be expected to lower the free $\mathrm{Mg}^{2+}$ concentration in both the growth medium and the cells.

\section{METHODS}

Schizosaccharomyces pombe, NCYC 132, ATCC 24751, was grown in Edinburgh Minimal Medium No. 2 (EMM2) (Mitchison, 1970) at $30^{\circ} \mathrm{C}$ in an orbital incubator operating at $160 \mathrm{rev}$. min $^{-1}$. Stock cultures were kept at $30^{\circ} \mathrm{C}$ in $10 \mathrm{ml}$ EMM2 and subcultured weekly. To induce synchronous division, analytical grade EDTA was added to exponentially growing cultures to a final concentration of $50 \mathrm{~mm}$ and the cultures were incubated for a further $60 \mathrm{~min}$. The cells were harvested by centrifuging at $30^{\circ} \mathrm{C}$ at $2500 \mathrm{~g}$ for $10 \mathrm{~min}$ and washed rapidly, by resuspension with $50 \mathrm{ml}$ distilled water at room temperature and further centrifugation, before being re-inoculated into fresh EMM2 at $30^{\circ} \mathrm{C}$. Control cultures, without EDTA, were treated identically.

Cell mass increase was followed by measuring absorbance at $595 \mathrm{~nm}$. Cell numbers were determined using a Thoma haemocytometer, applying the convention described by Mitchison (1970) that cells should not be taken to have divided until a notch could be detected on either side of the cell plate.

DNA was measured in yeasts from $100 \mathrm{ml}$ culture. The cells were harvested by centrifuging at $2500 \mathrm{~g}$ for $10 \mathrm{~min}$, resuspended in $10 \mathrm{ml} \mathrm{10 \%} \mathrm{(v/v)} \mathrm{perchloric} \mathrm{acid} \mathrm{and} \mathrm{stored} \mathrm{at}-18{ }^{\circ} \mathrm{C}$ overnight. On thawing, the cells were pelleted by centrifuging as before, resuspended in $5 \mathrm{ml} 10 \%(\mathrm{v} / \mathrm{v})$ perchloric acid and allowed to stand at $0{ }^{\circ} \mathrm{C}$ for $60 \mathrm{~min}$ before recentrifuging. The pellets were extracted twice with $5 \mathrm{ml}$ ethanol $(96 \%, \mathrm{v} / \mathrm{v})$ at $80^{\circ} \mathrm{C}$ for $5 \mathrm{~min}$ and then nucleic acids were extracted in $2 \mathrm{ml} 5 \%(\mathrm{v} / \mathrm{v})$ perchloric acid. (This volume might

* Present address: Department of Agricultural Biochemistry, Edinburgh School of Agriculture, Edinburgh EH9 3JG. 


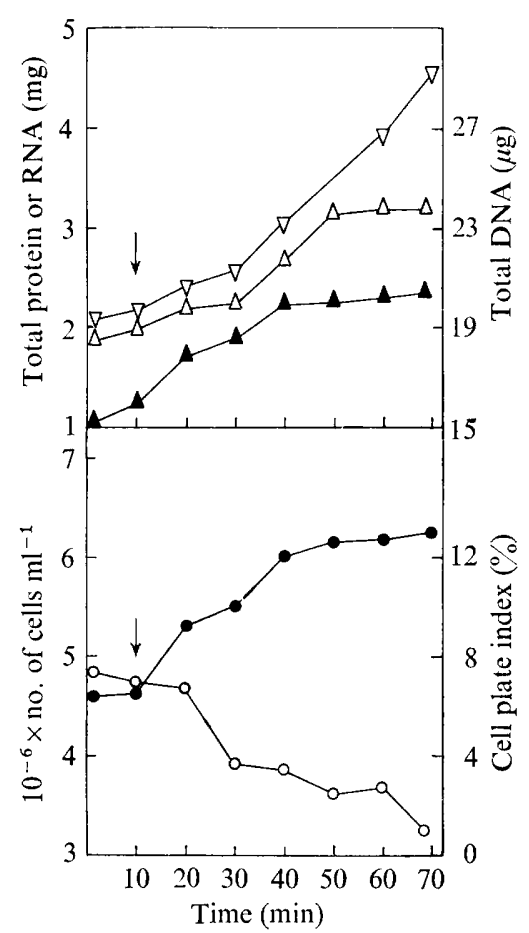

Fig. 1

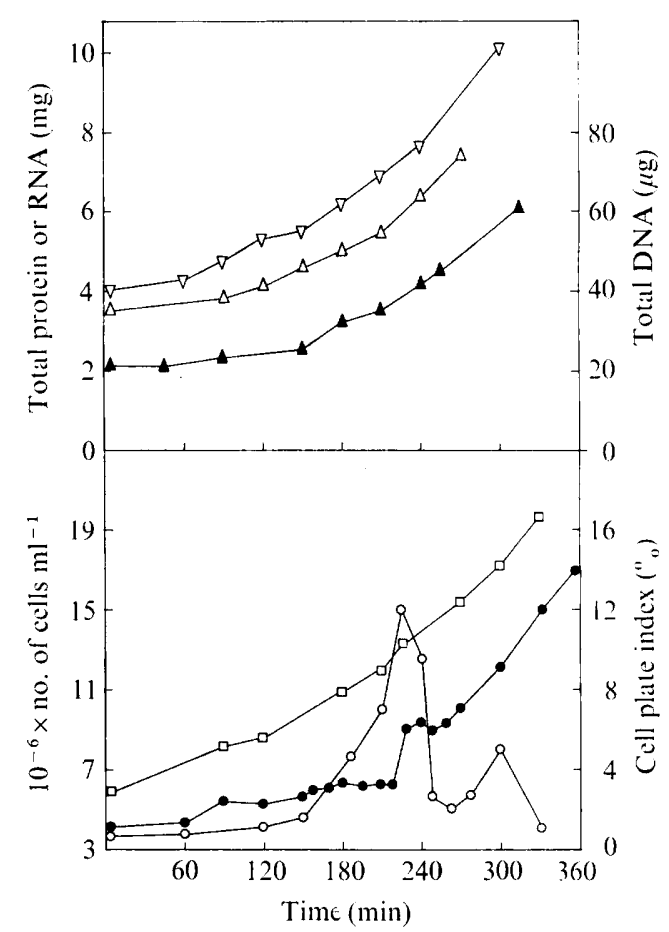

Fig. 2

Fig. 1. Bulk changes in protein, nucleic acids, cell number and cell plate index in a batch culture of $S$. pombe growing exponentially in EMM2 at $30^{\circ} \mathrm{C}$ to which EDTA (final concentration $50 \mathrm{mM}$ ) was added at the time indicated by the arrow. $\nabla$, Protein; $\triangle$, RNA; $\triangle$, DNA; 0 , cell number; $O$, cell plate index.

Fig. 2. Bulk changes in protein, nucleic acids, cell number and cell plate index in a batch culture of $S$. pombe following transfer from EDTA medium (50 mM in EMM2 for $1 \mathrm{~h}$ ) to fresh EMM2. $\nabla$, Protein; $\triangle$, RNA; $\Delta$, DNA; , cell number; $O$, cell plate index; $\square$, cell number, control culture (no EDTA treatment).

be varied depending on the size of the pellet.) Samples $(1 \mathrm{ml})$ of the extract were assayed for DNA by the method of Bostock (1970).

RNA was measured in the same extracts as used for DNA estimation; $0.1 \mathrm{ml}$ samples of the extracts were diluted with $1.9 \mathrm{ml}$ distilled water and the RNA content was assayed using the orcinol method (Mejbaum, 1939).

The pellets remaining after nucleic acid extraction were extracted in $5 \mathrm{ml} 1 \mathrm{M}-\mathrm{NaOH}$ at $60^{\circ} \mathrm{C}$ for $1 \mathrm{~h}$. Samples $(0.1 \mathrm{ml})$ of these extracts were made up to $2.0 \mathrm{ml}$ with distilled water and the protein content was determined by the method of Lowry et al. (1951), as described by Miller (1959), using bovine serum albumin solutions as the reference standards.

\section{RESULTS}

DNA accumulation was completely inhibited after 30 min exposure to 50 mM-EDTA while RNA accumulation was inhibited after $40 \mathrm{~min}$ exposure (Fig. 1). The increase in cell numbers gradually declined and ceased after $50 \mathrm{~min}$. On the other hand, total protein continued to increase during EDTA treatment. Cell mass increase (not shown) parallelled that of protein. Indeed, there appeared to be an acceleration in the rate of increase of these two properties of the cells so that they doubled during the 60 min incubation period. Longer periods of incubation became increasingly lethal.

When the cells were inoculated into fresh medium, about $48 \%$ divided asynchronously over a period of $220 \mathrm{~min}$ (Fig. 2). Then $45 \%$ of the total population divided synchronously 
over a period of less than $15 \mathrm{~min}$. The cell plate index showed a peak of $12 \%$ after $220 \mathrm{~min}$, just before cell division. After a lag, DNA accumulation resumed and increased in an exponential fashion with no marked indication of synchrony. RNA accumulation behaved in a similar fashion but seemed to resume more rapidly. The increase in total protein resembled that for RNA. The increase in total mass of cells continued exponentially but at a much slower rate than during the EDTA pulse. In the control cultures, asynchronous growth continued with a fairly constant cell plate index of about $6 \%$.

It was found that synchronous division of up to $50 \%$ of the cells could be obtained in a typical culture after exposure to EDTA for as little as $20 \mathrm{~min}$.

\section{DISCUSSION}

Duffus \& Paterson (1974b) reported that in synchronous cultures of Schizosaccharomyces pombe prepared by sucrose density gradient selection (Mitchison \& Vincent, 1965), the total cell $\mathrm{Mg}^{2+}$ concentration remained constant through the cell cycle. This suggested that the intracellular concentration of $\mathrm{Mg}^{2+}$ must fall continuously through the cycle as the cells grow in size and, further, that there must be a rapid and precisely controlled influx of $\mathrm{Mg}^{2+}$ close to the time of cell division so that the daughter cells could have the same total $\mathbf{M g}^{2+}$ content as the mother cell. Since microtubules are unstable at high $\mathrm{Mg}^{2+}$ concentrations (Borisy et al., 1974), this provides a model whereby spindle formation is permitted only at the end of the cell cycle when the $\mathrm{Mg}^{2+}$ concentration is low enough, and spindle breakdown is facilitated at the time of cell division by a $\mathrm{Mg}^{2+}$ influx. The effect of the divalent cation ionophore A23187, which inhibited progress through the cell cycle at a point just before cell division, presumably by preventing the net uptake of $\mathrm{Mg}^{2+}$ by the cells as a result of making the cell membranes readily permeable to these ions, seemed to support the above hypothesis (Duffus \& Paterson, 1974a). The results reported in this paper may be regarded as further evidence in its favour. No effects of EDTA on living systems other than those due to the ability to chelate divalent cations have so far been recorded. Thus it is reasonable to suppose that this is the crucial factor here. If so, the effects observed can be explained as follows. EDTA at the concentration used lowers the intracellular free $\mathrm{Mg}^{2+}$ level to a concentration which is too low for nucleic acid synthesis but which permits most other normal growth processes to continue, at least temporarily. The acceleration of growth indicated in the cell mass and protein measurements may reflect the increased availability of nucleoside triphosphates no longer required for nucleic acid synthesis. The effects on cell division fit in with the model derived from previous work in this laboratory, giving $\mathrm{Mg}^{2+}$ a crucial role in the volume-related control of the cell cycle and cell division, as described above. Thus the microtubule and consequential spindle formation supposed to be dependent on fall in $\mathrm{Mg}^{2+}$ concentration may be accelerated by EDTA influx until it is characteristic of the point of the cell cycle normally associated with the free $\mathrm{Mg}^{2+}$ concentration induced by the EDTA treatment. In effect, the intrinsic 'biological clock' controlling cell division has been reset by adjusting the $\mathrm{Mg}^{2+}$ concentration. This is a new phenomenon in the induction of cell synchrony since all other methods developed to date have relied on blocking the cell cycle at a specific point and allowing the cells to accumulate at this point. The question arises as to why only $50 \%$ of the cell population should be susceptible to synchronization by short-term exposure to $50 \mathrm{~mm}$-EDTA. Conceivably only cells which have just divided can respond, since they contain high concentrations of $\mathrm{Mg}^{2+}$, much of it only loosely bound to cell components and therefore readily chelated by EDTA. Towards the end of the cell cycle, a high proportion of the cell $\mathrm{Mg}^{2+}$ will be tightly bound and so the effect of the EDTA will be less.

Work is at present in progress to study the effects of other chelating agents, and also of $\mathrm{Mg}^{2+}$ deprivation by use of $\mathrm{Mg}^{2+}$-free media. Similar results have been obtained with Kluyveromyces fragilis and it is hoped that this technique will lead to more precise experimental control of the cell cycle than has hitherto been possible. 
This work was supported by grants from the Science Research Council.

\section{REFERENCES}

Borisy, G. E., Olmstead, J. B., Marcum, J. H. \& AlLEN, C. (1974). Microtubule assembly in vitro. Federation Proceedings 33, 167-174.

Bostock, C. J. (1970). DNA synthesis in the fission yeast, Schizosaccharomyces pombe. Experimental Cell Research 60, 626-627.

Duffus, J. H. \& Paterson, L. J. (1974a). Control of cell division in yeast using the ionophore A23187 with calcium and magnesium. Nature, London 251 , 626-627.

Duffus, J. H. \& Paterson, L. J. (1974b). The cell cycle in the fission yeast Schizosaccharomyces pombe: changes in activity of magnesium dependent ATPase and in total internal magnesium in relation to cell division. Zeitschrift für allgemeine Mikrobiologie 14, 727-729.

Lowry, O. H., Rosebrough, N. J., FARR, A. L. \& RANDALL, R. J. (1951). Protein measurement with the Folin phenol reagent. Journal of Biological Chemistry 193, 265-275.
Mejbaum, W. (1939). Estimation of small amounts of pentose, especially in derivatives of adenylic acid. Zeitschrift für physiologische Chemie 45, 83-89.

Miller, G. L. (1959). Protein determination for large numbers of samples. Analytical Chemistry 31, 964.

Mitchison, J. M. (1970). Physiological and cytological methods for Schizosaccharomyces pombe. Methods in Cell Physiology 4, 131-165.

Mitchison, J. M. \& Vincent, W. S. (1965). Preparation of synchronous cell cultures by sedimentation. Nature, London 205, 987-989.

Penman, C. S. \& Duffus, J. H. (1975). 2'-Deoxyadenosine and A23187 as agents for inducing synchrony in the budding yeast, Kluyveromyces fragilis. Journal of General Microbiology 90, 76-80. 